\title{
Local Wisdom in The Management of Forests in North Lombok Bayan Indigenous People
}

\author{
Libasut Taqwa \\ Universitas Indonesia \\ Abdurrahman Wahid Centre For Interfaith Dialogue And Peace \\ Universitas Indonesia \\ Depok, Indonesia \\ libasut.taqwa281@gmail.com
}

\begin{abstract}
In Indonesia, there are currently 57 million hectares of forest area controlled by indigenous people. 40 million hectares of which are still maintained. This is a comprehensive evidence of Indonesia's indigenous people role in keeping the forest in the midst of uncertain climate change. One of the indigenous groups that still exist are the Bayanese people at Bayan village in North Lombok regency, West Nusa Tenggara. The Bayanese still maintain their forests through a set of custom rules containing 23 principles related prohibitions, obligations, as well as forest preservation system that has lasted for hundred years called awiq-awiq. This research conducted at the Bayan Village, North Lombok. The research aims to find out how the significance of the awiq-awiq concept as the Bayanese traditional rules capable to preserve and manage indigenous forests for hundred years and credited with keeping the climate enhancement in North Lombok. In addition, the study also wants to elaborate how the awiq-awiq can implemented in a wider space in order to find solutions to global climate change.
\end{abstract}

Keywords-; Forest, Bayanese People, Awiq-Awiq, Climate Change, Management

\section{INTRODUCTION}

Geographically, North Lombok lies between (115 46 $\left.115^{\circ} 28\right)$ east longitude and between $\left(8^{\circ} 120-8^{\circ} 550\right)$ South Latitude with boundaries as follows: Sea of Java in the North, Straits of Lombok and West Lombok regency in the West, Central Lombok regency in the South, and East Lombok in the East. The North Lombok regency Topography in the north along into the middle of the mountain range are protected forest that serves as hydrology, while along the coast there is only a narrow and limited lowland. In the middle stretches from east to west, there is a fairly extensive lowland which is a fertile agricultural region. In the southern region there is a hilly plateau that serves as a buffer forest hydrology.

With these circumstances, North Lombok is very strategic because it is situated in a tourist destination. Furthermore, the North Lombok also has a cluster of small islands that quite famous for marine and coastal nature which called as Gili (which mean Island in Sasak Language): Gili Air, Gili Meno and Gili Trawangan.

Based on the Meteorology and Geophysics Agency (BMG), North Lombok classified as a tropical climates with ranging from 23.1 degrees Celsius temperatures. High temperatures occur in July-August of 32.9 degrees Celsius and the lowest 20.9 degrees Celsius in April. This geographical situation makes North Lombok regency divided into:
Mountain areas, the mountain range that stretches from Bayan district to Pemenang district. This mountain range is the source of the river that flowing into the areas of land and comes down along the coast. The hilly areas of Bayan District, Kayangan, Gangga, and most lowland region of the Gangga district, Tanjung, and Pemenang. Administratively, Bayan District now covers nine villages that consist of: Akar-Akar, Sukadana, Anyar, Senaru, Bayan, Loloan, Mumbul Sari, Sambi Elen and Karang Bajo. With approximately $29.32 \mathrm{~km} 2$ total areas. There are 107 villages and 314 households with a 45.792 inhabitants. 22.441 of which are males and 23.351 females with an area of $37.16 \mathrm{~km} 2$.

Bayan community has long had a specificity in terms of culture and indigenous people who consistently carry out processions and traditional rituals throughout the year as part of local tradition and hereditary society. According to that habitude, Bayan village frequently considered as the mother of all villages that developed from an indigenous Bayanese community because its legacy of the ancient mosque which called Bayan Beleq which is considered the oldest Mosque in Lombok. In addition, the Bayanese has maintain the survival of people and nature and preserve their forest for hundreds of years to bring harmony between man, nature, and the rules of customary law.

\section{METHOD}

This research was conducted by involved research methods that explored as a special case study in order to understand the phenomenon in depth. This is to see how social phenomenon seen in the frame and a unique perspective especially in a forest management system. This is a qualitative research with some data collection techniques as follows:

a) Study of the literature was conducted to look at the context of the Bayanese indigenous location that will underpin and find the relationship of every phenomenon that occurs in the process of indigenous forest management system.

b) The documents from the local resources such as the regulations of the local area become a secondary data to complete the research.

c) In-depth interviews (depth interview) will be made to group members and key figures. 
d) Observations made to observe how the everyday (behavioral analyst) groups of the Bayanese beliefs, in their social environment. This technique is needed to see how the Bayanese Philosophy used to view important aspects of the forest management system, including the elaboration how the awiq-awiq, as a costumary law can be implemented in a wider space in order to find solutions to global climate change.

\section{RESEARCH FINDINGS \& DISCUSSION \\ A. The Bayanese Philosophy of Life}

Hindu Balinese are thought to have first entered Lombok in the fourteenth century[1][2], and communities were established in West and Central Lombok by the fifteenth century[3]. Many are held to have been Javanese who were just passing through Bali for a generation or two on their way to Lombok. Most of these appear to have converted to Islam and were then immediately considered Sasak. More Balinese migrated to West Lombok in the sixteenth century and established permanent settlements. In the seventeenth century, Balinese forces defeated Sasak kingdoms and controlled the western half of the island until around 1740, when they gained control of the entire island. Until that time, Balinese fought fierce battles with both Sasak and Makassarese who had supported Sasak nobles and dominated parts of East Lombok and Sumbawa. Balinese culture was increasingly transplanted into Lombok in the eighteenth and nineteenth centuries, but Hindu Balinese presence intensified and unified opposition. This situation were not only colourized the Sasak tradition, but also the Bayanese, as their daily activities.

According to the history of the Bayanese, the acculturation between religion and culture has spawned a philosophical concept that called Wetu Telu as the basis of Bayan people. In line with it, the information from the North Sajang village people (neighbor Village of Bayan) confirmed that the concept of Wetu Telu actually appear and arise from Bilok Petung village in Sembalun district. It is characterized by the presence of some special form of Wetu Telu typical ancient relics like ancient manuscripts, sacred scripture and others. Furthermore, Even when in ancient Bayan Beleq mosque's restoration, the ingredients for the restoration must come from Bilok Petung [4][5]. Structurally, the Wetu Telu concept are led by a group of Mangku, Mekel, and Penghulu.

Each of these leaders is assumed to order in different fields. The Mangku have to order in a development side, economic, and others; The Mekel working in the field of governance; and Penghulu working in the field of religion. These three structural concepts then become teh Bayanese Adat which called as Wetu telu. This concept Therefore develop in a wider idea including all three things in human life. For example; three process of creatures that consist of born; life; and death. Three emergence of human being that is meranak (birth), the emergence of life as is the case with childbirth in humans and some animals such as cattle, Buffalo, Goat, and others; menteluk (spawn), as is the case in most animals, such as crocodiles, birds, poultry, etc; mentiuk (grown from seed), as occurs in plants. It is considered solidarity between the three sources of religious law; customs; and Government.
In different way, Budiwanti[6] explain that Wetu Telu Bayan, was the Sasak people that despite claiming to be Muslims, continue to revere the spirits of the ancestors and others in their local context. Budiwanti recognize this dichotomy is actually more like the term of Islam Abangan and in some respects Islam Santri in the dichotomy of Geertz on Javanese Islam. According these different definition of what the Wetu telu is, we can assumed that Wetu Telu is a concept of the Bayanese people way of life that makes a good relation and harmony not only with natural environment, but also with the human being, the Creature, and their ancestors. One of the embodiment of that harmonious relation is a rule of adat or customary law which includes the human and nature relationship which is called as Awiq-awiq.

\section{B. Awiq-awiq and The Forest Management System}

For hundred years, the Bayanese have inhabited in Bayan Village and run their ritual activities in a sustainable manner. The relationship between man and nature to be harmonious and complementary. In Bayan, According to Madi Kusuma[7], Head of Village, in taking and determine forest management, the Bayanese cannot decide anything before consultation (Musyawarah) and communally approved by the traditional leaders and community representatives so as to encourage the attitudes and habits of mutual assistance (Gotong-royong) in the Bayan community

The Bayan system of forest management culturally sistematized a hundred years ago. According to the Bayan people, Traditional Forest is All Forests belong to Indigenous land from Kepembekelan Karang Bajo like Pawang Singang Borot Karang Bajo, Pawang Bangket Bayan in Bayan Village area, and Pawang Gedeng Lauk in Loloan Village, and also Pawang Semokan in Sukadana district managed entirely by the Adat community and recognized by the local village government, respectively. With an area of forest that are not measured statistically but culturally, the management system rests entirely customary provisions. Indigenous device in charge of security affairs and the preservation of the forest are Mak Perumbak Dayak and Mak Perumbak Lauk also supported by all Adat people. Both forest managers have been hereditary and inherited by the descendants of men with lifetime tenure and the public unless the rules specify otherwise.

The main duties (as a part of Awiq-awiq) of Mak Perumbak Dayak, Mak Perumbak Lauk and also the community is to secure, protect and conserve the indigenous forest areas as well as all the historic heritage (Pengaci-aci) that is in the indigenous forest. It is also required to carry out reforestation with customary manner that required similar tree planting as existing in the forest before; those guardians and people should be visit (menjojo) the forests annually in accordance with the rules of using traditional clothes and local values in the area of Pawang Gedeng (Pawang Bangket Bayan) and Gedeng Lauk (Pawang Gedeng) on their foot from tengak- perumbak of Bayan village before the start of the growing season; the Guardians and the people (Bayanese) should also perform traditional rituals (Asuh) every year to ensure the forest sustainability and secure. 
To preserve the forest, the community agreed to create a prohibitions as a part of Awiq-awiq as described follows:

1. Illegal logging in indigenous forest are prohibited in any conditions;

2. It is not justified to burn any plants in forest areas with deliberate destruction of forest;

3. It is not justified in pawn, obtained some or all indigenous forest plants;

4. It is Prohibited to removal and displacement of indigenous forest boundaries;

5. It is Prohibited to cut the trees by using machines in indigenous forest areas;

6. It is wrong to hunt and murder all endangered species that live in the area of indigenous forest in any condition;

7. It is Prohibited to do the agricultural activities in the area of indigenous forest;

8. It is Prohibited to obtain a certificate for a part or the whole land of forest areas;

9. It is Prohibited to ring a variety of art tools in the indigenous forest areas;

10. It is not allowed to enter the area of forest without a permission from the indigenous forest guards (Mak Lokak Perumbak)

11. Not allowed to take a bath and wash any garments using soap that containing detergent in indigenous forests;

12. It is Prohibited to catch the water content (fishes, etc) with stun tools and hiss which containing toxins in the indigenous forest areas;

13. It is Prohibited to perform immoral action and activity across indigenous forests region;

14. It is Prohibited to move or destroy, pollute many relics across the indigenous forest (Pengaci-aci) either a part or all of them;

15. It is Prohibited to herd any animals across the forest region.

Violation of the 15 prohibitions above will be subject to fines or penalties which called as Dosa and apply according to the level of a violation of Awiq-awiq. The penalty can be either cattle or pay a pieces money with Kepeng Susuk, an ancient form of currency as a medium of exchange that is charged to the suspect of violation; Another severe sanctions in case of repeated violation after the punishment, the suspect then exiled to the outside of the village. This very strictly forest management pattern has become one of the basic preservation of forests for hundred years in North Lombok.

\section{The Bayanese Challenges}

Template According to Renadi[8], a history teacher in Bayan elementary school, admitted that when the potential of Bayan's natural resources began to be known in addition to the peculiarities of it cultures, including indigenous forest management, management dualism between customs authorities and the government began to appear. For him, today, the management of the tourism potential of indigenous Bayan is given to private parties "which is not the Bayanese." It will greatly affect the development of Adat values in the future, because it is managed not by the indigenous peoples themselves. In addition, the sustainability of the indigenous forests slowly began dormant. Aside from the rapid modernization by the government of North Lombok regency, the Pawang (Guards) and forest rangers have died and have no successor. Son of the Pawangs, who is expected to become the successor prefer to work outside the city.

Like as Renadi, Jambi Anom[9], a former activist of Nusantara Indigenous People Alliance (Aliansi Masyarakat Adat Nusantara), argued that with the opening access of tourism, Bayanese young generation lost their interest in learning the customs of their ancestors. "They prefer to be a Guide for the foreign tourists, rather than learning Bayan traditional values" From observation for a few days, the authors conclude that the interest of the youth is concentrated in the tourism sector and not the adat values or Philosophy. In contrast, many of them forgotten and not even know the values and knowledge of the indigenous forest.

The dilemma of Bayan community also began to be seen especially when the village government issued Karang Bajo Regulation No. 01, 2006[10] concerning Indigenous Forest Conservation. This regulation unfortunately were not in accordance with the local rules on Bayanese management values and boundaries of the forest that potentially break the unity of society.

\section{CONCLUSION}

The exposure of the awiq-awiq concept as the Bayanese traditional rules assumed that its capable to preserve and manage indigenous forests for hundred years. In addition, this rules can implemented in a wider space in order to find solutions to global climate change as long as can withstand with the demands of modernization and globalization. Furthermore, the Bayanese have to protect and anticipate the emergence of their young generation because of its fragility from the modernization and commercialization of Adat and the traditional values.

\section{ACKNOWLEDGMENT}

Many thanks to Abdurrahman Wahid Centre, Universitas Indonesia, and all of the Bayan People in North Lombok for a humble greetings to help me to complete this research.

\section{REFERENCES}

[1] David Harnish, "Isn't This Nice? Its Just Like Being in Bali: Constructing Balinese Music Culture in Lombok." Ethnomusicology Forum. Vol. 14, No.1, Routledge: Taylor \& Francis, Ltd. Jun. 2005. pp. 3-24

[2] David Harnish, "Digging" and "Upgrading": Government Efforts to "Develop" Music and Dance in Lombok, Asian Music, Vol. 38, No. 1 (Winter - Spring, 2007). University of Texas Press. pp. 61-87

[3] Hans Higerdal, Hindu Rulers, Muslim Subject: Lombok And Bali in the Seventeenth and Eighteenth Centuries. Thailand: White Lotus Co Ltd, 2001.

[4] Kendra Clegg, "Ampenan: A Constructions of Nationality, Ethnicity, And Identity in Urban Lombok." Ph.D. dissertation, Deakin University, 2004. 
[5] Arnis Rachmadani, "Local Wisdom Tradisi Perkawinan Islam Wetu Telu sebagai Perekat Kerukunan Masyarakat Bayan.” Harmoni, Jurnal Multikultural \& Multireligius. Volume X, Nomor 3, Juli - September 2011. Jakarta. pp. 662-680

[6] Erni Budiwanti, Islam Sasak; Wetu telu versus Waktu Lima Yogyakarta: LKiS, 2000.

[7] Interview with Madi Kusuma, Head of Local Government of Bayan Village, October 2015
[8] Interview with Renadi, History teacher of Bayan Elementary School, October 2015

[9] Interview with Jambi Anom, former activist of Nusantara Indigenous People Alliance (Aliansi Masyarakat Adat Nusantara), October 2015

[10] Karang Bajo Local Government Regulation No. 01, 2006 concerning Indigenous Forest Conservation. 